\title{
The Impact of European Structural Funds on Romania’s Local Administrative Management Development
}

\author{
Monica Tesu \\ The Bucharest University of Economic Studies, Bucharest, Romania
}

\begin{abstract}
The public sector is particularly suitable to the scope of the analysis for several reasons such as the strong multidimensionality of the activity. Additionally, in many countries, such as Romania, the public sector was one of the most affected by managerial reforms. The main aim of this paper is to propose a model for measuring the performance of the administrative management, the indicators which influence the performance of the civil servants. As is set out in 1303/2013 EU (European Union) Regulation, and in documents prepared by the commission on the position of the commission services on the development of the partnership and programs in Romania for the period 2014-2020, The Strategy for Strengthening Public Administration, was enacted by the publication of Decision No. 909/2014, representing ex-ante conditionality. By publishing The Strategy for Strengthening Public Administration, in Romania were created the premises by the 2020 step, to the administration to evolve to the point where citizens will benefit from quality public services, integrated by public institutions pro-active, responsive, implementing the tempo rapid changes required. The theoretical approaches and also the practice in public management, revealed the benefit of the Strategy Europe 2020, which implementation on the public administration in Romania, analyzing the training of civil servants is a necessity for developing public capacity.

Keywords: public management, European Union grants, the Operational Program for Administrative Capacity Development 2007-2013, administrative development of the public management, citizens, civil servants, local government
\end{abstract}

Christopher Hood has conceptualized formally since the 1980s, the term "New Public Management (NPM)", which materializes line of government policy, which aims to modernize and streamline the public sector. Rhodes described NPM UK (Rhodes, 1991, p. 1) as a,

System where the emphasis is not placed on the policy management, performance and efficiency, downsizing the bureaucracy, the introduction of competition in the public space, cost reduction, a management style that emphasizes results not processes, use of limited term employment contracts, civil responsibility.

Organization for Economic Cooperation and Development (OECD), NPM defines the "decentralization, management by objectives, outsourcing". NPM is results-oriented and efficiency, the trend of more efficient use of public funds and better management of the state budget. According to the NPM, private consumers are defined as "beneficiaries of public services and citizens are regarded as shareholders; public institutions are

Corresponding author: Monica Tesu, Drd., The Bucharest University of Economic Studies, Bucharest, Romania, counselor on Ministry of Regional Development and Public Administration; research field: management on public administration. E-mail: monica.tesu@yahoo.ro. 
defined by principles of efficiency, underlying economic principles and leadership".

Changes in the public sector since 1980, applied in a number of OECD countries were essential for the development of NPM and led to changes in the doctrines concerning public accountability and best practices.

Implementation of NPM, as an alternative, incorporates gradually ideas of modernization in public administration. Internationalization and a new global paradigm in public management, creates considerable variation. The researchers also argues that the explanations conventional breeding NMP, "seem difficult to sustain even from an inspection relative letter to inquire transnational that are available, and indeed the explanation based on the initial allocation can give us insight different on these changes” (Pollitt \& Bouckaert, 2004, p. 19).

\section{The State's Role in Providing Public Services}

The emergence of regulation as a form of social policy is, therefore, a change in the descriptions and concepts of those who carried out social policies, because it is a real change in institutions and policies. The new state regulation is seen by Leisering and Mabbett, as a part of the ongoing transformation of the welfare state, "the post-war welfare state as a state provider with a focus on public provision and redistribution" (Leisering \& Mabbett, 2011, pp. 3-4).

The non-commercial collective public service, meets the objectives of removing the gaps in the market by subsidizing, to enhance the economy positive factors which are attached services (environmental protection, research, infrastructure) and to bring services to citizens, making them accessible even to the poor people by offering them for free or at a lower price than their production (educational services, health services).

A public policy set by government is,

A set of measures taken by a legal authority and responsibility to improve the living conditions of citizens or designing incentives for economic growth. It provides, in general, dialogue correlation of the various actors and the lessons learned from their institutional and personal experiences. (Profiroiu \& Iorga, 2009, p. 17)

A public service includes three elements, namely: a mission that the state has an obligation to meet a series which satisfies the mission as well as goods and financial resources to carry out the mission. (Duguit, 1907, pp. 416-417)

Sharing the "Power" between public and private, is an important feature of the perspective contemporary on governance as it differs from the government a centralized state, but also it is the "triangles iron composed of politicians, managers, public and private, and leaders of corporatism old” (Majone, 2011, p. 45). In this sense, "Rule can be understood as a shift from hierarchies to networks, with greater emphasis on partnerships and joint governance” (Rhodes, 2006, pp. 425-447).

"Unity in diversity" is a concrete reality of European social models, by which EU (European Union) member states have evolved according to its own socio-economic development in line with the history of their collective in each of these national models being mentioned a number features common European stability public pension system, the system of health care and welfare, regulations on labor market models redistribution through tax policies and a set of common values-European "solidarity and cohesion, equality and the fight against all forms of discrimination, health and safety at work, universal access to education and health, quality of life and quality of work, sustainable development and the involvement of civil society”, as iterated in the work basis administration public (Profiroiu, 2010, p. 65). 
The macroeconomic Romanian society context, in the last five years, has been dominated by the experience of the effects of the economic crisis, which started in Romania since 2009 when it was officially declared recession. The crisis was caused by deep miscorrelations between sectors and fields of the economy, between the nominal economy and the real economy, between supply and demand, or the flows of goods and services, human flows of information and knowledge flows and monetary-financial and capital. The economic crisis, with deep reverberations in political, social, scientific, educational, environmental life, revealed the weakness of management in almost all countries of the world, from the USA world leader and reaching Africa, Asia, or Latin America (Profiroiu, Nicolescu, \& Verboncu, 2011, p. 100).

Strong economies have managed the 2009-2013 global economic crises with more chance of success than the governments of less developed countries, but the shock waves have spread faster and slower in countries with subsistence-based economies. In Romania, the crisis was felt by appreciation of currencies against local currency (Romanian leu), measures to limit the decline in purchasing power, increasing of value added tax from $19 \%$ to $24 \%$. All these measures were felt directly in the pockets of the citizens, rising unemployment and lower wages in several industries, including the budget system. Small businesses, without state protection went quickly to bankruptcy, reducing the state budget revenues.

After a good agricultural year in 2011, the economic crisis has weakened in Romania; this influenced the revenue growth rate. The economic crisis was felt in 2012 with an advance of $0.7 \%$. The austerity measures in Romania have led to decreases in imports and exports, reductions of foreign investments, which are expected to resume in 2014.

The causes of Romania's crisis, have been identified by a research organization of the National Council of Small and Medium Enterprises in Romania. By interviewing 228 entrepreneurs and managers, participants Romanian Top Private Companies, were collected figures and analyzed the result that some of the causes of the crisis in Romania in the opinion of those interviewed fiscal instability, late payment or non-payment by state by enterprises, policy loans from state banks, public management with great political influence (O. Nicolescu, Verboncu, C. Nicolescu, \& Anghel, 2011, p. 80) (see Figure 1).

As a conclusion, the global economic crisis through its effects, revealed how a government can handle the global challenges. The measures to stop the crisis were targeted in Romania directly to the weakest social categories that were not protected at all by crisis: the citizens (rising the unemployment and lower the wages) and onto the low-protected small businesses (a large percentage went to bankruptcy), who were most exposed.

Public administration in Romania consists of central and local public administration, central government - composed of ministries and other central bodies of the government in supervision or control, the prefect with the apparatus of the prefecture. The foundation of administrative decentralization in Romania leads to the organization of the territory into administrative-territorial units under the Constitution's Art. 3, consists of villages, towns, and counties, conducted to the local government. According to constitutional provisions, Romania realized administrative decentralization, in respect for the principles of "local autonomy" and “decentralization of public services”. Under the constitution's provisions, the public local authorities have local autonomy in communes and towns, local or county councils. Local authorities, elected by universal, equal, direct, secret, and freely expressed are composed of deliberative authorities-local council and the executive authorities — the mayor and his specialist apparatus. 


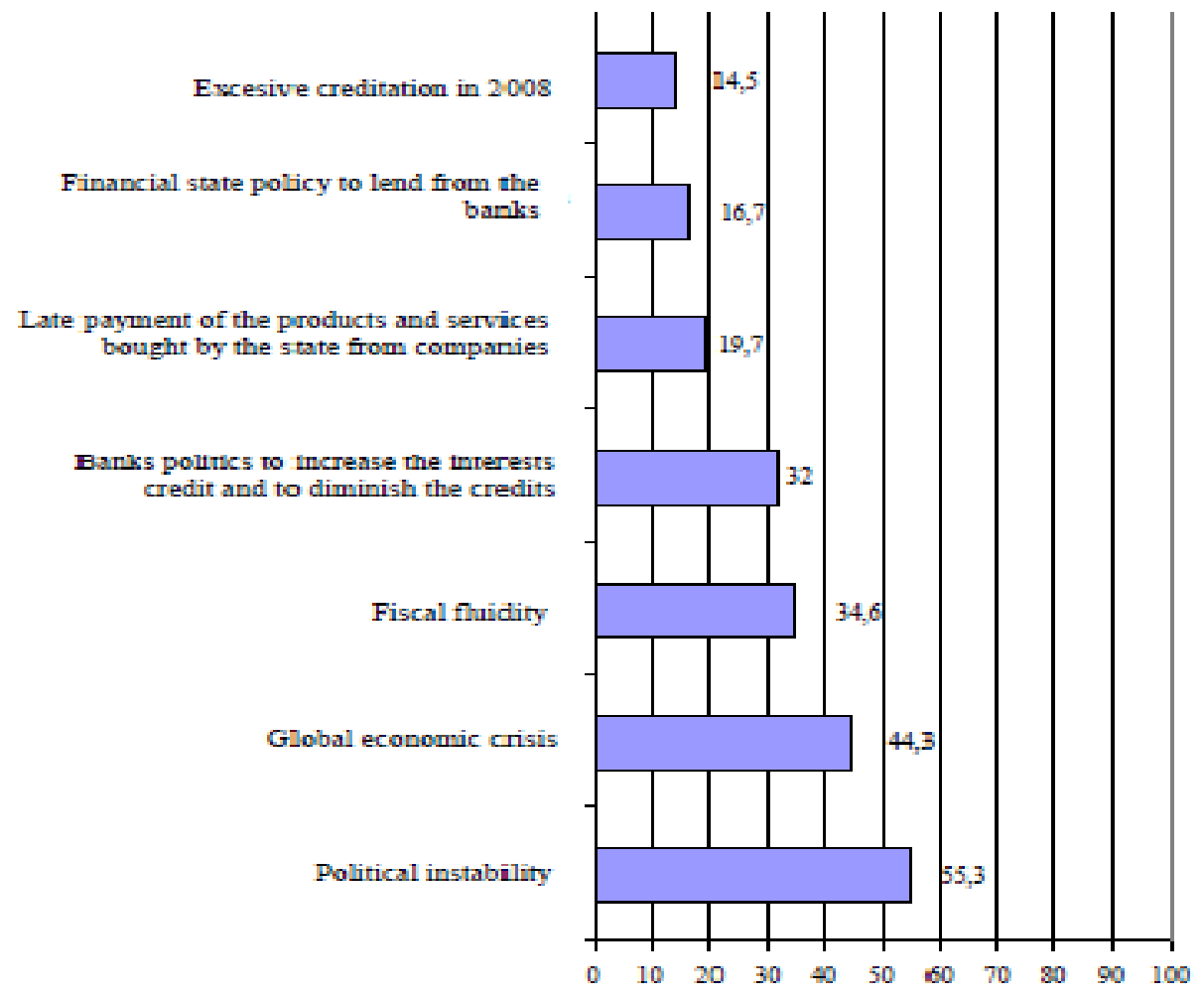

Figure 1. The main causes of the crisis in Romania. Source: Nicolescu et al. (2011).

\section{Presentation of the Romanian Public Administration}

According to the principles of administrative decentralization, there is no subordination between local versus central authorities. It is also noted an important element of administrative decentralization, as "no authority of central government", has no power to interfere on documents issued by local authorities, only the prefect may appeal to the administrative court a considered unlawful act issued by the mayor, County Council, or City Council. The Local Public Administration Law No. 215/2001 republished, with its subsequent amendments, governing management principles of local autonomy, competence and duties of local authorities.

According to The 2014-2016 Fiscal Budgetary Strategy, it established the main objectives of fiscal and budgetary policy, providing resources for sustainable economic development, further fiscal consolidation measures to stimulate economic growth and create new jobs, increase revenue faster than expenses, create an efficient tax system, together with an increased concern budgetary revenue collection and transparency in use of public funds and using best practice examples. Strengthening the National Budget, strengthening the fiscal institutions in accordance with the agreements signed by "The Fiscal Pact", it will be accompanied by rigorous monitoring of government indebtedness, by strengthening of the fiscal discipline, increasing its collection by paying arrears to the state budget, and local and preventive measures against increasing the arrears, and by measures of increasing the efficiency of use of budget allocations as a result of reforming "The Public Investment Expenditures”, and increasing implementation of European projects co-financed by EU funds, and the encouraging those investments with high performance and those which can be completed in a medium-time-horizon. 
The targets set at European level by "The Europe 2020 Strategy", are related to employment, research and development, climate change and sustainable use of energy, education and combating poverty and social exclusion and achieve these goals. Public administration plays a key role in coordinating the implementation of policies and actions that create the framework for achieving them. Administration will adopt innovative solutions, with competent human resources and efficient management of the funds, offering prompt service, proposing solutions, the beneficiary of the trust of citizens.

\section{Weaknesses of Romania's Public Administration}

Some of Romania's public administration weaknesses are excessive-politicization, low of motivation of human resources, few career opportunities, low motivational policies, and low rate of wages for civil servants had, and the instability due to political changes among executive civil servants.

As a result of many studies, the measures for strengthening the public system to be applied in Romania, are beyond the de-politicization of the system, and change the principle of the entire system, a new system which promote new rules like promoting best practices, management based on high level of ethics and equity, developing skills in public administration. Administration will adopt innovative solutions, human resources competent and efficient management of the funds, offering prompt service, proposing solutions. Analysis of the structural causes that led to the reduction of administrative capacity in Romania, according to a document drafted at the request of the European Commission approved by the Prime Minister in December 2013, into consideration, the politicization of the administration, personalized approach to management decision-making institutional and frequent re-organizations of public institutions. Another major problem affecting good governance is public misallocation of resources, which is a cause and an effect of inconsistency and mandates often exchanged in public administration. Partial overlapping of powers between central government structures, county, local, affects budgetary allocations resulting in disparate policies and plans regarding redundancies in legislation being found normative acts in the human resources management and use of IT (information technology), the lack of inter-database connectivity in public administration.

Budgetary constraints caused by the economic crisis will not lead to an oversight of the professional civil servants who lack the attractiveness of the incentive system in public administration and remuneration lead to inflow of public servants who leave the system, leading to de-professionalization risk public institutions. Administrative capacity development involves analyzing these structural causes and effects of stopping them.

Through a modern approach, government should focus on dedicated purpose of providing public services and the implementation of the law through quality public services in order to achieve its purpose, facilitating socio-economic development. Specific objectives include increasing transparency in decision-making, increase predictability of action institutions at central and policies that they manage, administrative-territorial reorganization, clarifying the division of powers between central government and local adaptation of human resources requirements modern administration, measures to reduce and prevent corruption, recommendations of the MCV ${ }^{1}$.

\footnotetext{
${ }^{1}$ Mechanism for Cooperation and Verification is a process of verification of the progress that Romania and Bulgaria have in terms of judicial reform, corruption and organized crime. Romania has applied to join the Cooperation and Verification Mechanism. To help the two countries to resolve these important issues, the EU decided to establish a "mechanism for cooperation and verification" specially designed to ensure a harmonious accession process and also to protect policies and institutions. In December 2006, the European Commission set out a number of criteria ("benchmarks") for assessing progress in these areas. On January 1, 2007, when Bulgaria and Romania became EU countries, the two countries still had to resolve certain objectives related to judicial reform, reducing corruption in state institutions and putting control of organized crime. Source: https://ro.wikipedia.org/wiki/Mecanismul_de_Cooperare_\%C8\%99i_Verificare.
} 
It is essential to strengthen administrative capacity for the provision of quality public services, allowing the maximum efficiency and accessibility to the final beneficiaries. Citizen relates to public services, assessing government performance. To ensure increased quality of public services, it is important to develop implementation mechanisms for quality standards and cost, enabling public institutions and authorities measure the quality of service, allowing public authorities to streamline the use of resources by using economies of scale achieved by the provision of common public services, while allowing access to additional expertise.

In conclusion, local government authorities should be responsible for providing most public services, managing consistent financial resources by creating the necessary mechanisms to ensure predictability of revenue streams within the administrative-territorial units, to prioritize correlation of investment needs, local needs, and promoting measures to increase their revenue and implement efficient measures of budget implementation, increasing efficiency of local management.

\section{Project Financing From European Union Grants}

The European Commission manages the structural funds financial instruments, whose purpose is to support the structural level. The structural funds are intended to provide financial support to less developed regions, strengthening cohesion in the EU. Structural funds contribute to the strategic objectives of the EU on the economic and social way, promoting specific objectives - the convergence objective or reducing disparities between regions [for regions that have a GDP (gross domestic product)/capita below 75\% of the European average], the regional competitiveness and employment objective which means that the state can apply for funding for regions not eligible for the convergence objective, the European territorial cooperation objective (modernization in the structure of the education and employment system).

The system of absorbing the EU funds can be categorized a minus-point-system, by analyzing the degree of absorption of those funds in the first period (2007-2013). Although, in 2012, Romania faced the risk of suspension of some of the components, the risk of disengagement has been avoided and payment declarations were processed by the system. Shortcoming of the locally system is the conduct of difficult projects financed from European funds, due to frequent legislative changes, the long period of implementation of new measures and regulations, and the need to correlate activities with other institutions state. The financial corrections in the system, significant amounts were lost, putting pressure on the state budget; additional funds are needed to complete them with money from the state budget.

Stage of absorption nine months before the curtain falls, following European Funds Ministry ${ }^{2}$, is presented below. With a low percentage, representing a half of total allocation, Romania was on a low stage (see Figure 2).

\section{PO DCA (The Operational Program for Development of the Administrative Capacity)—The Program Created to Modernize Public Administration in Romania}

The task of modernization of public institutions, was major supported by PO DCA-the Operational Program for Administrative Capacity Development 2007-2013, which correspond to the tasks of funding projects aimed to develop procedures and methodologies which will grow Romanian administrative capacity, creating policy proposals on which recommendations were formulated and organizing training sessions for employees beneficiaries.

\footnotetext{
2 http://www.zf.ro/eveniment/guvernul-isi-asuma-sa-transfere-in-deficit-sumele-ce-nu-vor-fi-decontate-de-ue-pe-programele-de rulate-cu-fonduri-europene-14135726.
} 


\begin{tabular}{|c|c|c|c|c|c|c|}
\hline Programme & $\begin{array}{l}\text { Amount } \\
2007-2013\end{array}$ & $\begin{array}{c}\text { Absorption } \\
31 \text { dec. 2014 } \\
\text { (mil. euro) }\end{array}$ & $\begin{array}{c}\text { Absorption } \\
31 \text { dec. } \\
\% \text { Of total allocation }\end{array}$ & $\begin{array}{l}\text { Ab sorption } \\
31 \text { mart. 2015 } \\
\text { (mil. euro) }\end{array}$ & $\begin{array}{c}\text { Absorption } \\
31 \text { mart. } 2015 \\
(\%)\end{array}$ & $\begin{array}{l}\% \text { Growth } \\
\text { comparisons } \\
\text { to } 31.12 .2014\end{array}$ \\
\hline PQR & 3.966 & 2.186 & 55,1 & 2323 & 58,5 & 3,4 \\
\hline PO Mediu & 4.413 & 1.755 & 39.7 & 1.823 & 41.3 & 1.6 \\
\hline $\begin{array}{l}\text { POS } \\
\text { Transport }\end{array}$ & 4.426 & 2.209 & 49,9 & 2.507 & 58,4 & 8,5 \\
\hline POS CCE & 2.554 & 1.249 & 48.9 & 1.249 & 49.2 & 0,3 \\
\hline POSDRU & 3.476 & 999 & 27,7 & 1.158 & 33,3 & 4,6 \\
\hline PODCA & 208 & 150 & 72 & 161 & 77,5 & 5,5 \\
\hline PO AT & 170 & $\pi$ & 45 & 100 & 58,7 & 13,7 \\
\hline Total & 19.213 & 8.625 & 44.9 & 9.321 & 48,9 & 4 \\
\hline
\end{tabular}

Figure 2. Stage of Romanian absorption (March 31, 2015). Source: Romanian Ministry of European Funds.

Although the absorption rate PO DCA according to the Ministry of European Funds, stood at the end of 2014 at 70\% and the contracted rate was 123\% of the ESF (European Social Fund) allocation to PO DCA, and in November 2015 was 89\%, but the actual impact of implementation of the projects is limited, influenced by causes like the fragmentation of funding (which means low values projects), spread across central and local government, their orientation directions without major approach inter-sector and the absence of initiatives for reforming the civil service and the management of public services.

Local government needs are based on new ways of management more efficient and developing, especially IT and E-government development, providing the opportunity for coherence and efficiency. These tools require the mobilization of substantial financial resources, which may come from attracting European grants for the convergence objective.

The administrative capacity development from three perspectives-civil service needs, the instruments used to meet those needs, and the institutional context that affects the civil service, are the priorities of PO DCA. The training of public servants is the primary focus for improving the impacts in the future, between the challenges of improving the public services sector (education, health care, social assistance), and the strengthening the role played by PO DCA in the process of reforming the public services in Romania.

How will improve the citizen's life, developing a modern administration, based on trained civil servants? And, how will limit the impact of projects of the small jurisdictions (small communities/small villages)?

In answering this question, the author made an econometric study which analyzes the administrative capacity of the major development regions in Romania, in relation with the GDP per capita and rate of life and other indicators.

This chapter aims that through econometric analysis of data provided by the Managing Authority for PO DCA—operational program dedicated to improving public administration management, identify opportunities for the implementation of local development projects through PO DCA. The analysis aims to find initially priority directions chosen beneficiaries PO DCA for writing projects, which may provide evidence about the real development needs of management in local government, this need can be found by centralizing data on the priority axes and key areas Intervention PO DCA.

The Implementation Framework Paper Commitments for 2007-2013 period of PO DCA, consists in some indicators which are periodic calculating and report for information of the beneficiaries. To achieve and measure objectives in the National Strategic Reference Framework to strengthen administrative capacity, PO 
DCA established a series of output indicators (“output”), indicators of results ("result”), and additional indicators for measuring the results. These indicators, according to the priority axis and key area of intervention, for the approved projects, are reported by periodic statements accompanying applications for refund. The expected result anticipates central and local accountability, strengthening framework to provide a well-founded basis to be reflected in the implementation of future strategic choices.

\section{Budgetary Sources}

The program's budget was 208 million euro for period 2007-2013, secured financing from the European Social Fund, plus co-financing, for a total of 244.70 million euro. Through its priority axes (structured on areas of intervention), it was adapted for modernization of local and central government, with the direct beneficiaries of public authorities, local and universities, non-governmental bodies.

PO DCA is financed by the European Community contribution through the European Social Fund (85\%) and through national public contribution (15\%), with ERDF (European Regional Development Fund)'s components on $10 \%$ of the EU funds (the acquisition of capital assets), and $90 \%$ coming from the ESF (training component, professional development). It gives importance to developing partnerships between public and private bodies or other stakeholders, aims to increase the confidence of citizens in public administration, improving the responsiveness of institutions to public needs by creating new structures, simplified change and redeployment of achieving administrative simplification structures. The operational program aims to improve substantially decentralized public services locally and centrally efficiency by saving resources and improving the quality of outcomes and implement the principles of sustainable development ${ }^{3}$.

\section{What Projects Are Financed by PO DCA}

Projects have been submitted for the operations of improving decision-making at political and administrative (KAI-Key Area of Intervention 1.1), which had as its object sustainable development strategy at county level, strengthening institutional capacity to manage reform on improving the environment business, effective decision-making at local government level, scenarios of developing socio-economic and demographic at small towns and counties, and developing strategic and regional planning for rural regions.

To improve organizational effectiveness (KAI 1.3), projects submitted and approved, include strategies for strengthening the training of employees of county's councils, responsible for reduce risks at county-level through better communication, development of administrative capacity for administration at local ranging eligible activities guide the development and delivery of training programs, including implementation of curricula and teaching materials in all relevant areas, such as public procurement, European Computer Driving License, foreign languages, project development, project management, sharing best practices and their wide application, study tours, seminars, conferences for capacity building of public administration employees to increase organizational efficiency. To support decentralization processes sectored service were submitted projects for effective social services comprising decentralization through optimization, efficiency and professionalism, promptness at the local government level, projects for the health sector (KAI 2.1). The projects made to improve the quality and efficiency of service delivery (included in KAI 2.2) were included projects for finding innovative management, simplifying procedures of electronic document management solutions, better and faster services for the citizens.

${ }^{3}$ Source: http://ec.europa.eu/esf/main.jsp ? catid = 526 \& langId = en. 
On the first analysis of the data provided, we can see the situation of the projects submitted, the projects approved and the projects not approved, the eligible amount of contracted projects, approved, paid, divided by region, shown in the following figure, it is seen that out of a total general 1,353 projects submitted, in which the Bucharest-Ilfov Region has a total of 427 projects submitted, of which 185 are considered valid (with a total value of 3.8 billion lei-approx. 70 million euro) of which the eligible projects submitted and validated is one billion lei.

Among developing regions, except the Bucharest-Ilfov Region (1.314 billion lei), in the top are the Center Region with a projects approved in value of 0.05 billion lei, and the North-East Region with 0.04 billion lei (see Table 1).

Table 1

Summary Projects Submitted, on Romania's Regions, by PO DCA

\begin{tabular}{|c|c|c|c|c|c|c|}
\hline \multirow[b]{2}{*}{ Region } & \multirow{2}{*}{$\begin{array}{l}\text { Total } \\
\text { number of } \\
\text { projects } \\
\text { deposed }\end{array}$} & \multicolumn{2}{|c|}{ In which } & \multirow[b]{2}{*}{$\begin{array}{l}\text { Total value of } \\
\text { the projects }\end{array}$} & \multicolumn{2}{|c|}{ In which } \\
\hline & & $\begin{array}{l}\text { Number of } \\
\text { rejected } \\
\text { projects }\end{array}$ & $\begin{array}{l}\text { Number of } \\
\text { approved } \\
\text { projects }\end{array}$ & & $\begin{array}{l}\text { The value of } \\
\text { rejected projects }\end{array}$ & $\begin{array}{l}\text { The value of } \\
\text { approved projects }\end{array}$ \\
\hline 1. The North-East Region & 187 & 143 & 44 & $132,184,903$ & $92,813,651$ & $39,371,252$ \\
\hline 2. The South-East-Dobrogea Region & 179 & 122 & 57 & $105,673,841$ & $71,699,162$ & $33,974,679$ \\
\hline 3. The South-Muntenia Region & 149 & 103 & 46 & $167,951,356$ & $137,553,396$ & $30,397,960$ \\
\hline 4. The South-West Oltenia Region & 62 & 40 & 22 & $38,801,240$ & $24,135,663$ & $14,665,577$ \\
\hline 5. The West Region & 64 & 44 & 20 & $50,160,753$ & $40,114,740$ & $10,046,014$ \\
\hline 6. The North-West Region & 128 & 99 & 29 & $95,042,887$ & $59,672,956$ & $35,369,931$ \\
\hline 7. The Center Region & 157 & 108 & 49 & $118,905,408$ & $66,823,713$ & $52,081,694$ \\
\hline 8. București-Ilfov Region & 427 & 242 & 185 & $3,124,834,837$ & $1,810,671,136$ & $1,314,163,702$ \\
\hline Total & 1,353 & 901 & 452 & $3,833,555,224$ & $2,303,484,416$ & $1,530,070,808$ \\
\hline
\end{tabular}

Note. Source: http://www.fonduriadministratie.ro.

Notable is the fact that on the period of 2007-2013, a proportion of $66 \%$ of all projects were approved. A coherent strategy to encourage resources for developing the projects based on European Union grants, means ensuring a continuous and sufficient flow of capital, or that projects may be considered "Losses".

The graph of the major developed regions of Romania, presents GDP per capita during the period 2007-2009, and statistical dates about the most develop major regions from Romania, which is the Bucharest-Ilfov Region, with double values as the West Major Region of the country, on the opposite the poorest region from Romania is the North-East Region ${ }^{4}$ (see Table 2).

Below, the author presents the map of the projects approved for the local administration-deposed by local mayors of small towns, villages, developed under the PODCA 2007-2013 auspices. We can see the highest number of projects approved on the Region of Bucharest-Ilfov (with 185 projects), and on the other side, the West Region, has the lowest one with a number of 22 projects.

The analysis notes that the annual series are available, for the period 2007-2013, considered optimal for testing variables amount eligible were considered data of the 2009 year, contenting information about the ineligible amount, number of training sessions completed, approved projects, the number of analyzes created in

4 The dates are selected from the National Institute of Statistics: http://www.insse.ro/cms/files/Web_IDD_BD_ro/ O1/O1_3-PIB\%20pe\%20locuitor\%20pe\%20regiuni\%20.xls. 
the PO DCA approved projects, number of strategies, number of participants in training certified, days of training of the participants, number of training sessions.

Table 2

GDP per Capita, on Romania's Regions

\begin{tabular}{llll}
\hline & & & GDP per capita \\
\hline National aggregation level & 2007 & 2008 & 2009 \\
\hline Total Romania GDP per capita & $19,315.4$ & $23,934.6$ & $23,341.4$ \\
1. The North-East Region & $12,340.9$ & $14,794.5$ & $14,649.3$ \\
2. The South-East-Dobrogea Region & $15,641.8$ & $19,098.9$ & $18,738.2$ \\
3. The South-Muntenia Region & $15,757.8$ & $19,648.1$ & $19,913.7$ \\
4. The South-West Oltenia Region & $15,097.3$ & $17,831.8$ & $17,752.8$ \\
5. The West Region & $22,341.9$ & $26,173.2$ & $25,602.4$ \\
6. The North-West Region & $18,610.5$ & $21,542.1$ & $21,297.4$ \\
7. The Center Region & $19,579.5$ & $22,707.7$ & $22,618.8$ \\
8. București-Ilfov Region & $43,037.3$ & $59,680.2$ & $55,079.3$ \\
\hline
\end{tabular}

Note. Source: National Institute of Statistics (currency: Romanian leu).

The variables in source come from PO DCA data base, and direct links with the local government management performance, and the other variables were selected from official territorial statistics (INS website, Tempo-Online) in an attempt to determine other factors that directly or indirectly may affect the performance management of a public administration in Romania, classified by counties.

The research was aimed at assessing the impact of implementation of projects financed by external funds on local economic development at local government level. The analysis was based on the relations of influence on the development, derived from the theory and from the practice, using analysis of variance and a suite of econometric regression models.

Statistical tests commonly deal with statistical analysis of the relationship between two variables called "attributes" that correspond to the same group of objects. To identify the causal relationship, the author studies the linkages between the two characteristics measured on data from some basic common characteristics. Thus, the author studies the causal relationship between two or more statistical series in which couples of values (xi, yi), correspond to the couple of statistical variables (X, Y). The ultimate goal is forecasting in the condition that the two variables are indeed correlated, thus analyzing possible associations between two or more values of statistical variables, taken from the same group.

Interpreting statistical correlation between two variables will be made by one correlation coefficient, which takes values between -1 and +1 , passing through 0 , which indicates an unassigned between the two variables (independence). A value of $\mathrm{r}$ close to -1 , indicates a strong negative correlation, that is a variable tendency to decrease significantly while the other variable increases, while a value of $\mathrm{r}$ close to +1 , it indicates a strong positive correlation, that is, the trend of increasing a significant variable when the other variable increases. It is noted that there are cases where the dependent variable correlation coefficients zero (see Figure 3). 


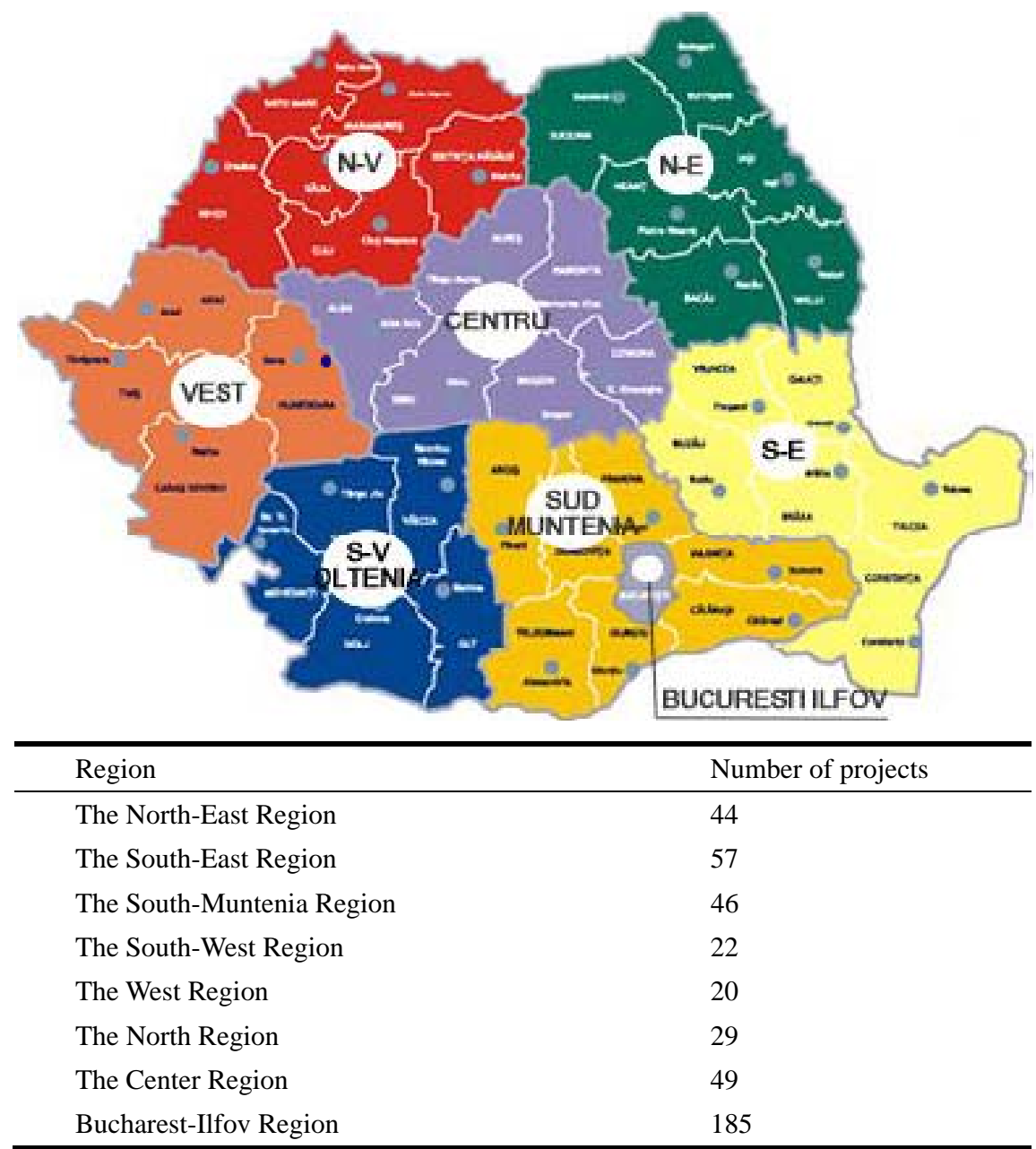

Figure 3. Number of projects deposed on PO DCA by major regions, from Romania. Source: http://www.fonduriadministratie.ro.

\section{Linear Regression}

As a methodology, the dependent variable is distributed on the axis of ordinates, while the independent variable is distributed on the $\mathrm{x}$-axis. The regression equation is determined by using the "least squares" (Least Squares Method) which, intuitive, minimizing the distance between pairs of data points represented and the corresponding points on the line (obtained through proper verticals). This distance is called residue (residual). We get the regression equation form:

$$
\mathrm{Y}=\mathrm{a}+\mathrm{bX}
$$

Where "a" it is called interceptor and "b" is the regression coefficient.

In this case, instead of predicting the dependent variable value in relation to the values of the explanatory variables, the forecast will be a transformation of the dependent variable called logit transformation, designated as logit(p), where "p" is the proportion of objects with a certain characteristic (e.g., "p" is the probability that the number of studies, analyses, reports, strategies to overcome the media, or "p" is the probability that the number of participants in training sessions to overcome media certified). Formula after which we calculate logit(p) is: 


$$
\ln \left(\frac{\hat{\pi}}{1-\hat{\pi}}\right)=b_{0}+b_{1} x_{1}+b_{2} x_{2}+\ldots+b_{k} x_{k}
$$

If the dependent variable is not a continuous variable but a binary one, a categorical one, if the dependent variable refers to two values (categories), no longer used multiple regression, but a new analysis using logistic regression.

By logistic regression, the author studies the relationship between the variables: number of studies, analyses, reports, strategies and number of participants in certified training sessions.

We have number of observations equal to 40 , the number of counties (Note: Two counties were excluded without projects approved).

After analyzing the 40 cases studied, we see that performance $=1$, if variable number of studies, analyses, reports, and strategies is greater than 10 (average), and also the variable number of participants in the training sessions certify exceed $>212$ (average). Otherwise, the performance is equal to 0 if the number of studies, analyzes, reports, media strategy is under 10 and number of participants in the training sessions of 212 . Certified exceeds the calculated average performance dependent variable is the probability model is performance $=1$ (see Table 3).

Table 3

Variable Which Influences Variable Studies, Reports, Analyses, and Strategies

\begin{tabular}{lllll}
\hline Parameter estimates & & & \\
Explanation & $\begin{array}{l}\text { Parameter } \\
\text { estimate }\end{array}$ & $\begin{array}{l}\text { Standard } \\
\text { error }\end{array}$ & Value of test t & Pr $>|t|$ \\
\hline Intercept & -3.40833 & 22.11273 & -0.15 & 0.8787 \\
Number of participants in the training sessions certify & -0.00520 & 0.00568 & -0.92 & 0.3680 \\
Number of approved projects & 0.93421 & 0.92651 & 1.01 & 0.3226 \\
Value of approved projects & 0.00000191 & 0.00000178 & 1.07 & 0.2929 \\
Number of day of training & -0.00009954 & 0.00015153 & -0.66 & 0.5170 \\
Population with higher education—on year 2009 & 0.00105 & 0.00169 & 0.62 & 0.5402 \\
Rural population on year 2009 & 0.00001606 & 0.00004510 & 0.36 & 0.7247 \\
Urban population on year 2009 & -0.00004780 & 0.00006162 & -0.78 & 0.4449 \\
Number of days per each curse of training & 0.03996 & 0.08428 & 0.47 & 0.6394 \\
Population with higher education on year 2009/Total & -1.19045 & 9.79026 & -0.12 & 0.9042 \\
Urban population on year 2009/Total & 0.21724 & 0.50978 & 0.43 & 0.6735 \\
Number of training session & 0.13719 & 0.10179 & 1.35 & 0.1894 \\
GDP per capita 2009 & -0.00017631 & 0.00014524 & -1.21 & 0.2357 \\
\hline
\end{tabular}

Considering the frequency of cases, we have 35 observations when performance $=0$, and we have five observations when performance takes value 1 . Testing the case when performance is 0 , we have the same kind of results.

Initially, the model is not taken any variables into account at the first stage, the software SAS shall enter the variable most significant with $p$-value $=0.0001$, respectively the number of participants in the training certificate and the 2nd stage to introduce variable with $p$-value $=0.0405$, number of studies, analyzes, reports, strategies, and testing the entire model with two variables and observe that $p$-value $=0.0753$, so the number of 
studies, analyzes, reports, strategies no longer significant, and algorithm stops at this point, because it was removed from the final model variable added.

Number of participants from the variable coefficient certified training is positive (0.00456), which means a direct link to local public management performance. Performance management in local government is directly and positively influenced the number of certified participants in the training sessions. The counties in which high level civil servants who have undergone training sessions or training (and have them completed by obtaining a certificate of completion), are the best in terms of public administration management, performance is seen indirectly the ability to develop analyses, studies, and local development strategies.

Table 4

The Variable List-Results Indicators per Project (With Key Descriptive Statistical Parameters Aggregated per Counties)

\begin{tabular}{|c|c|c|c|c|c|}
\hline Name of the variable & $\begin{array}{l}\text { Observations } \\
\text { No. }\end{array}$ & Average level & $\begin{array}{l}\text { Standard } \\
\text { deviation }\end{array}$ & Minimum & Maximum \\
\hline Number of projects conducted by PO DCA & 40 & 5.225 & 4.1105711 & 1 & 16 \\
\hline $\begin{array}{l}\text { Studies, analyses, reports, strategies run by civil } \\
\text { servants conducted by PO DCA }\end{array}$ & 40 & 10.05 & 10.4610388 & 0 & 41 \\
\hline $\begin{array}{l}\text { Certified participants on training courses (number) } \\
\text { conducted by PO DCA }\end{array}$ & 40 & 212.675 & 322.534307 & 0 & 1,354 \\
\hline Eligible value conducted by PO DCA & 40 & $2,457,617.97$ & 2,079,783.93 & 0 & $10,436,991$ \\
\hline Non-eligible value conducted by PO DCA & 40 & $5,274.15$ & $9,355.88$ & 0 & $42,370.6$ \\
\hline $\begin{array}{l}\text { Number of training days for each participant (number) } \\
\text { conducted by PO DCA }\end{array}$ & 40 & $6,465.78$ & $8,484.12$ & 400 & 49,616 \\
\hline $\begin{array}{l}\text { The population with higher education/total population } \\
\text { (year 2009) }\end{array}$ & 40 & $4,546.45$ & $11,826.84$ & 0 & 71,972 \\
\hline The rural population (year 2009) & 40 & $224,641.43$ & $93,138.1$ & 0 & 436,420 \\
\hline The urban population (year 2009) & 40 & $281,021.48$ & $292,185.09$ & 87,564 & $1,944,367$ \\
\hline The average life expectancy (year 2009) & 40 & 69.8325 & 14.5679967 & 7.16 & 75.29 \\
\hline High trained population/total population & 40 & 0.5631164 & 0.8746567 & 0 & 3.8193659 \\
\hline Urban population/Total population (year 2009) & 40 & 50.9121041 & 13.8047702 & 30.8718652 & 100 \\
\hline Number of training sessions & 40 & 17.425 & 18.3175515 & 0 & 89 \\
\hline GDP per capita (year 2009) & 40 & $20,573.92$ & $8,640.22$ & $10,699.2$ & 57,285 \\
\hline $\begin{array}{l}\text { Number of personal computer/1,000 people (year } \\
\text { 2009) }\end{array}$ & 40 & 14.3598981 & 6.718259 & 7.3042115 & 49.071084 \\
\hline
\end{tabular}

As a result, in 35 counties of the 40 observed, we have results as compiling reports and strategies under 10 per county low score due to low participation in training, given that the other five counties the number of civil servants who participated at training sessions and have been certified exceed the average of 212 per county (see Table 4).

In conclusion, local performance is directly influenced by continuous improvement, in other words, knowledge - one of the objectives of the European 2020 Strategy $^{5}$, needs to be taken in consideration on the life time due to the direct influence on the management performance.

\section{Conclusions of the Test}

Starting from a base of raw data, the author concluded that the situation contains data for the period 2007

${ }^{5}$ http://ec.europa.eu/europe2020/index_en.htm. 
to 2014, the base was filtered using appropriate indicators of 2009, eliminating the basis of projects submitted by the central authorities, NGOs (non-governmental organizations), universities, it remains a database with local management authorities, and it is performance in management, the same time with the development of administrative capacities, and the satisfaction of their citizens.

The analyzed database, contained statistical variables to records at the county level as Population With Higher Education Year 2009, The Rural Population Year 2009, The Urban Population Over 2009, Average Life Expectancy Year 2009, High-Educated Population/Total Population-Year 2009 (Percentage), Urban Population in the 2009 Total Population (Percentage). The database contains records for 15 variables (all digital) in 40 observations (counties) and variable ( $\mathrm{N}$ ) corresponds to the number of observations (40).

Of the total 453 projects that were covered by the initial database, were excluded as the number and value of projects initiated by central government authorities, the projects submitted by higher education institutions and projects submitted by non-governmental organizations, thus remaining in the sample a number of 207 projects, funded from external grants initiated by local government authorities, with a value of 116 million eligible (amount in local currency—Romanian leu).

\section{Conclusion}

Econometric modeling logistic regression imposed by creating instrumental variables, which we named a performance that can take discrete values of 1 or 0 . After applying logistic regression model, we can conclude that performance management in local government is influenced positively by certified number of participants in the training sessions. The counties with most civil servants trained by professional trainings are the best in terms of public administration management, the ability to develop analysis and studies. The other variables have not significantly influenced in the model created.

\section{How Does Improve the Interval 2007-2013 Experience on 2014-2020 One}

The indicators of 2007-2013 PO DCA implementations without central support are ineffective due to the implementation, at the micro-level development strategies, which are broken spatially and non-coherent in that specific county. On the newest period of programming 2014-2020, the approach of more strategic projects with strong impact on the public system, will not be created at municipal and village level, several municipalities will submit joint projects for their areas, which will lead to better levels of development of the respective counties. In March 2015, it will be approved next program for 2014-2020 period, named the Operational Program for Administrative Capacity (POCA 2014-2020) with a budget of 658.29 million euro, for the same purpose (2.7 times than the previous one), of which EUR 553.19 million the allocation of ESF, the rest being provided from the national contribution of Romania. A new purpose for POCA 2014-2020 is the task of developing administrative capacities on justice authorities (central or local).

The question which it will lead to further analyzes is: The centralized strategies of developing the local administrative management—after 25 years past from the fall of communism—will produce better results? The future, it will prove it.

\section{References}

Duguit, L. (1907). Journal of Public Law and Political Science, Paris, France, pp. 416-417.

Leisering, L., \& Mabbett, D. (2011). Introduction: Towards a new regulatory state in old-age security? Exploring the issues. In L. Leisering (Ed.), The new regulatory state: Regulating pensions in Germany and the UK (pp. 1-28). Houndmills, Basingstoke, Hampshire: Palgrave Macmillan. 
Majone, G. (2011). The transformations of the regulatory state. In L. Leisering (Ed.), The new regulatory state: Regulating pensions in Germany and the UK (pp. 31-56). Houndmills, Basingstoke, Hampshire: Palgrave Macmillan.

Nicolescu, O., Verboncu, Nicolescu, C., \& Anghel. (2011). 2011 Romanian management assessment: Diagnosis and solution based upon 1988 interviews (p. 80).

Pollitt, C., \& Bouckaert, G. (2004). Public management reform: A comparative analysis (2nd ed.). Oxford, Great Britain: Oxford University Press. Retrieved from https://books.google.ro/books?hl=ro\&lr=\&id=rei8DGQQoooC\&oi=fnd\&pg= PR9\&dq=pollitt+public+administration\&ots=APfSyM00Eq\&sig=19axsUqTeSCCobgrqzTFZdw7Kbo\#v=onepage\&q=pollitt \%20public\%20administration \&f=false

Profiroiu, A. (2010). Bazele administrației publice (Fundamentals of public administration). Bucharest, Romania: Economic Publishing House.

Profiroiu, M., \& Iorga, E. (2009). Manual de politici publice (Public policy handbook) (p. 17). Bucharest, Romania: Public Policies Institute.

Profiroiu, M., Nicolescu, O., \& Verboncu, I. (2011). Starea de sanatate a managementului din România din 2010 (The health of the management in Romania in 2010). Bucharest, Romania: Pro Universitaria Publishing House.

Rhodes, R. A. W. (1991). Introduction. Public Administration Review, 69, 1-2.

Rhodes, R. A. W. (2006). Policy network analysis. In M. Moran, M. Rein, and R. E. Goodin (Eds.), The Oxford handbook of public policy (pp. 425-447). Oxford: Oxford University Press. 